Marquette University

e-Publications@Marquette

$1-1-2000$

Naturalizing, Normativity, and Using What "We" Know in Ethics

Margaret Urban Walker

Marquette University, margaret.walker@marquette.edu

Accepted version.The Version of Record of this manuscript has been published and is available in Canadian Journal of Philosophy, Supplementary Vol. 26 (2000): 75-101. DOI. (C) 2000 Taylor \& Francis. Used with permission.

Margaret Urban Walker was affiliated with Fordham University at the time of publication. 


\title{
Naturalizing, Normativity, and Using What "We" Know in Ethics
}

\author{
Margaret Urban Walker \\ Department of Philosophy, Fordham University \\ Bronx, NY
}

The provenance of "naturalized epistemology," so-called, is too recent for the hand of Quine not to be still heavily upon it. But like its older relative, "naturalism," it is an idea rich enough to be coveted, and protean enough to be claimed, by diverse comers with different things in mind. While Quine's version of naturalized epistemology of science inevitably furnishes the backdrop for current discussion of naturalizing moral epistemology, it is important to pause over what "naturalized epistemology" can and should mean in ethics. To what extent is Quine's example of an epistemology of science that helps itself to science the model for understanding knowledge of and in morality? Does it require a view of moral knowledge as reducible to, or in a fundamental way furnished by, science? Or a view of moral theory as science-like in some way? I argue that the appropriate analogy is instead a holistic and reflexive epistemology of morality that helps itself to moral judgments and standards seen as answerable to the experience of the kinds of shared lives they make possible and necessary. This approach neither privileges nor rejects wholesale what scientific inquiries might have to say. In the spirit of naturalized epistemology, it holds the importance of science to moral understanding subject to what else we think we know, including what we know morally.

My aim is to show that there are choices here that are deeply enmeshed in views about science, knowledge, and morality. I take morality, and hence the object of moral theorizing and moral epistemology, to be real-time, culturally embedded practices of responsibility. I see moral philosophy as a reflective but (for that reason) empirically burdened theoretical practice that is epistemically reflexive and normatively critical. ${ }^{1}$ There is no question here of trying 
to defend the view as a whole; instead I want to illustrate how it exemplifies some features of a naturalized conception, with the effect of steering attention in directions that moral philosophers have been slow to go, and perhaps resistant to going.

My specific, interested, and constructive appropriation of naturalized epistemology is as loaded as anyone else's is going to be. But this is only "natural," in the relevant epistemological sense: there is no epistemic position outside (a great deal of ) our knowledge. But where - that is, on what knowledge - we stand as we seek new understanding or revisions in the understanding we possess, and what some of "us" think of as "our" knowledge, is a question that must be opened. I am going to suggest our response to it should be morally and politically self-conscious, as well as epistemologically "freewheeling"

\section{How Quine "Naturalized Epistemology}

In "Epistemology Naturalized," Quine argued that, with the failure of reduction programs that promised firm foundations for mathematical and scientific knowledge, science might just as well explain itself. 2 "Epistemology, or something like it, simply falls into place as a chapter of psychology and hence of natural science" (EN 82), whose job is to study the actual construction of a picture of the world from scant sensory inputs. Quine is unconcerned about the circularity of using empirical science to validate empirical science, since there is no alternative knowledge of our knowledge. "We are after an understanding of science as an institution or process in the world, and we do not intend that understanding to be any better than the science which is its object" $(E N, 84)$.

This move immediately and persistently raised the question whether Quine's naturalized epistemology recaptured the normative mission of traditional epistemology to explain what constitutes adequate justification and real knowledge. The role of norms in scientific knowledge in Quine's naturalized epistemology is debatable. ${ }^{3}$ Quine's view seems to be that the cognitive equipments of human creatures disciplined by "pragmatic" inclinations, like conservatism in theory change, simplicity of laws, and of course the ultimate "empiricist discipline" of predictive success, are quite good enough. Our inquiry into "how it is done" in science will reveal what it is like for

Canadian Journal of Philosophy, Vol. 75, (2000): pg. 75-101. Publisher link. This article is (C) Taylor \& Francis and permission has been granted for this version to appear in e-Publications@Marquette. Taylor \& Francis does not grant permission for this article to be further copied/distributed or hosted elsewhere without the express permission from Taylor \& Francis. 
it to be done well, for science is our best case of natural knowledge. Its practice embodies what is to be done, as well as what is done, in this pursuit.

In the conclusion of another essay from the same period, Quine's triumphal teleology of natural science emerges unabashed. As he has it there, in the passage from reliance on our innate similarity sense, through intuitive understandings of similarity, and then to the scientific definition of theoretical kinds with explanatory significance, which need not owe anything to the innate similarity sense, "the animal vestige is wholly absorbed in the theory" providing us a "paradigm of the evolution of unreason into science." It is also an example of natural knowledge that spurs further knowledge which in turn rejects or corrects the original knowledge, or puts it into its newly discovered place. Yet this looping process by which what we (think we) know is corrected as we go farther on its very basis, has for Quine a direction. Even as we "live by bread and basic science both," it is science to which human sapience "rises." 4

In naturalized epistemology as Quine first styled it under that name, we have the usually remarked elements of holism (the "web of belief" vs. foundationalism), fallibilism (any of our previously credited beliefs could be found in need of rejection or revision) and naturalism (there is knowledge of the world only through its limited sensory impacts on us, no knowledge a priori). These together disqualify an indefeasibly privileged epistemic position that epistemology as an normative tribunal of all knowledges would have to occupy. But there is also the scientism, the vision of science as the mature culmination of all natural knowledge, science as that knowledge in and of the world than which there is not any better. ${ }^{5}$ This makes science the operative normative tribunal for other kinds of knowledge of the world as well as all of its own parts (but never, of course, all at once). ${ }^{6}$

\section{The Science Question in Moral Epistemology}

Quine's founding discussion of naturalizing epistemology suggests a certain prototype of that enterprise: a global scientifically regimented holism and a particularly scientific naturalism. I argue now that this is but one option, and not the best one, for naturalizing moral

Canadian Journal of Philosophy, Vol. 75, (2000): pg. 75-101. Publisher link. This article is (c) Taylor \& Francis and permission has been granted for this version to appear in e-Publications@Marquette. Taylor \& Francis does not grant permission for this article to be further copied/distributed or hosted elsewhere without the express permission from Taylor \& Francis. 
epistemology. Here is a generic prototype version (NE) of a broadly "Quinean" argument for naturalizing the epistemology of scientific knowledge. Without vexing the question about Quine's views, I build into this prototype the demand that epistemology have a normative dimension. I build this in because I think even philosophers who place themselves far distant from the search for foundations of knowledge are nonetheless reasonably disinclined to view anything as an epistemology that does not issue in at least, to use Hilary Kornblith's generous phrase, "constructive advice on the improvement of our epistemic situation."7 Of course, in a naturalized epistemology, normative insight must be compatible with epistemology's being a kind of natural knowledge within the world, available through uncontroversial human cognitive capacities; the normative dimension must not interject itself from somewhere else, or enter through claims to insight prior to or beyond all experience. A normative dimension does not require that epistemology introduces some sui generis constraints, values, or standards from somewhere outside actual epistemic practices of several kinds. It might, for example, reflectively retrieve standards immanent in epistemic practices and try to understand relations of those standards to the practices themselves and to other standards of those practices, as well as to standards of other practices. I also use "real knowledge" as a dummy expression for whatever conditions for beliefs' being warranted one wants to plug in. ${ }^{8} \mathrm{I}$ am interested in exploring a structural parallel here, and I try to leave this schematic prototype extremely general. This will allow us to study some options for naturalizing moral epistemology in extremely simplified and broad form, as well as to see where the "normative" element reappears differently in the case of moral understanding.

(NE): The epistemology of science seeks to tell us under what conditions we have real knowledge of the world.

So, epistemology must have a normative dimension, its inquiries must distinguish conditions under which we are likely to have genuine knowledge of the world from those under which we have something else (belief that is not warranted).

There is no kind of purely nonempirical knowledge that could validate scientific knowledge.

Canadian Journal of Philosophy, Vol. 75, (2000): pg. 75-101. Publisher link. This article is (C) Taylor \& Francis and permission has been granted for this version to appear in e-Publications@Marquette. Taylor \& Francis does not grant permission for this article to be further copied/distributed or hosted elsewhere without the express permission from Taylor \& Francis. 
NOT THE PUBLISHED VERSION; this is the author's final, peer-reviewed manuscript. The published version may be accessed by following the link in the citation at the bottom of the page.

There is no empirical knowledge with validity superior to scientific knowledge.

So, there is no kind of knowledge that does not include scientific knowledge that can be used to establish the validity of scientific knowledge.

So, the account of how we have real knowledge of the world must itself become another application of science, i.e. we will have to use (presumptively genuine but always in principle fallible and revisable) scientific knowledge (our best knowledge and its methods) to explain the conditions under which we come to have such a thing as genuine scientific knowledge.

Now let's explore straightaway one direct extension of this prototype for naturalizing epistemology in the case of moral knowledge (NME1).

(NME1) The epistemology of moral knowledge tells us under what conditions we have real knowledge of how we ought to live.

Moral epistemology must have a normative dimension, its inquiries must distinguish conditions under which we have genuine knowledge of how we ought to live from those under which we have something else (beliefs about how to live that are not warranted).

Moral knowledge is one kind of knowledge about the world (rather than about a transcendent or non-natural realm).

Moral knowledge is knowledge about which understandings of how to live are "valid" (true/right/acceptable/deserving of authority).

So, there is no kind of purely nonempirical knowledge that could validate moral knowledge.

There is no kind of empirical knowledge about the world, including moral knowledge, with validity superior to scientific knowledge.

There is no kind of knowledge outside of scientific knowledge that can better be used to establish the validity of moral knowledge.

Canadian Journal of Philosophy, Vol. 75, (2000): pg. 75-101. Publisher link. This article is (C) Taylor \& Francis and permission has been granted for this version to appear in e-Publications@Marquette. Taylor \& Francis does not grant permission for this article to be further copied/distributed or hosted elsewhere without the express permission from Taylor \& Francis. 
So, the account of how we have real knowledge of how we ought to live becomes another application of science. I.e. we will use some (presumptively genuine but always in principle fallible and revisable) scientific knowledge (our best knowledge and its methods) to explain how we come to have such a thing as genuine knowledge of how we ought to live.

I have represented the matter of moral knowledge here under the generic idea of "how we ought to live." I assume this place holder can accommodate views with deontological, consequentialist, virtue and other elements, so long as these are views about how we ought to live. I have for the purposes of this discussion assumed that people express, defend, wonder and argue about, and teach their children beliefs about how to live, and that the question about moral knowledge involves asking whether such beliefs are or could be warranted. ${ }^{9}$ I have included the "naturalistic premise" that moral knowledge is a kind of knowledge about this, our actual, world. Although a naturalist need not go in for naturalizing epistemology in morals or elsewhere, it is hard to imagine anyone interested in naturalizing moral epistemology not being some kind of naturalist about morality. But the idea that moral knowledge is in and of the world is meant in a fairly undemanding sense. It does not imply narrower naturalist commitments about moral properties or facts; it only suggests, on a parallel with NE above, that such knowledge as we may have of how to live is gotten in the world by ordinary cognitive capacities from our experiences of the world, which include our experiences of living with others and thinking about how we and others act and live. ${ }^{10}$ Finally, I leave open the characterization of the validity of beliefs about how to live in order to leave open the possibility that multiple ways in which to live might be "validated" by inquiries into morality, and that there are different forms that this "validation" might take. Again, I think this allows for the structural parallel to emerge at a high level of generality.

This model raises a problem widely associated with scientifically naturalized moral epistemology, the "loss of normativity." Scientific theories with explanatory power and predictive value may tell how morality arises, is seated in our native capacities, and is transmitted in communities with more or less continuity, without being able to say

Canadian Journal of Philosophy, Vol. 75, (2000): pg. 75-101. Publisher link. This article is (c) Taylor \& Francis and permission has been granted for this version to appear in e-Publications@Marquette. Taylor \& Francis does not grant permission for this article to be further copied/distributed or hosted elsewhere without the express permission from Taylor \& Francis. 
whether any extent forms of morality are morally better or worse than others. ${ }^{11}$

Naturalized epistemology of science might at least plausibly claim to have recaptured epistemology's normative role from within science, to the extent that sciences are successful practices of knowledge of how the world in fact is in some respects. In their respective domains with respect to the kinds of explanatory and predictive powers for which we want that kind of knowledge, sciences deliver what we want. We want to know how things work, in particular how the structures of things explain how they work; where applicable, we hope by knowing how things work to anticipate what they do, and make them do what we want them to, and not what we don't. Welldeveloped bodies of scientific theory deliver this, and deliver more of it as they are extended and refined. Thus many of us are already as sure as we can be (having given up on Cartesian certainty), that we have some of what we want and it will pay to follow the patterns by which we got it, at least if we want more of that. This is why, except to the philosophical skeptic, proposing to vet claims to knowledge by appeal to the ways we get such knowledge as science gives does not simply jettison the pursuit of norms, but supposes that much of science as practiced embodies the relevant norms. That is, the several sciences embody such norms as conduce to obtaining the kinds of knowledge at which they respectively aim. (And that the norms in play at any given time are revisable does not mean that at any given time there are not norms.)

The relevant norms for moral knowledge, however, would have to be the ones owing to which moral knowledge delivers what is wanted from it. We want moral knowledge in order to know how to live. This is what beliefs embodied in actually practiced morality or the simplified theoretical constructions of normative moral theory tell us: the necessity, importance, or superior value of, for example, human dignity, eternal salvation, the greatest happiness, harmony with nature, the preservation of natural hierarchies, proper respect for ancestors, nonviolence and universal compassion, or more or less coherent combinations of these or others. If the going moral norms (what we think we know morally, theoretically or on the hoof) successfully produce what is wanted in their respective forms of life, the question nonetheless remains open: is this a form of life we should

Canadian Journal of Philosophy, Vol. 75, (2000): pg. 75-101. Publisher link. This article is (c) Taylor \& Francis and permission has been granted for this version to appear in e-Publications@Marquette. Taylor \& Francis does not grant permission for this article to be further copied/distributed or hosted elsewhere without the express permission from Taylor \& Francis. 
want? This version of naturalized moral epistemology seems to have no way to supply the kind of normativity involved in people's living as they really ought to live. And if moral inquiry in either its philosophical or nonacademic versions is to retain its normative identity as an inquiry into what is really right or good, into how human beings get right how they ought to live rather than how they variously in fact do, it seems that moral inquiry must be something other than a purely scientific investigation.

This is not to deny that empirical findings of a scientific sort might fulfill a part of the empirical burden of moral philosophy. Insofar as moral epistemology needs, as it does, to understand what people know in understanding how to live as they in fact do morally, to that extent the parallel holds. Scientific studies of several types, for example, might well help us understand how people come to master the moral concepts in use, recognize the patterns of behavior their extant morality requires or suppresses, and cultivate the perceptions and feeling responses that enable people to bring expression and action into morally appropriate play, both in fulfilling moral demands or ideals as well as in understanding the terms of deserting or defying them. A very important part of moral epistemology is the investigation of the actual conditions of moral competence of various kinds. Naturalized moral epistemology should be eager to reap the benefits of whatever scientific studies of individual capacities or group processes successfully explain how we are able to share a way of life and to learn how to live within it (which does not always consist in living in accordance with it). ${ }^{12}$ But this robustly empirical study, ripe with potential for scientific contributions, leaves us one question short of philosophical ethics. The missing question is: no matter how successfully some group of people sustain a way of life they happen to live, is the way they live how they ought to live? A naturalized moral epistemology that has been absorbed into scientific studies might give us the best accounts we can have of how they do it, without yet touching in what sense they should.

Just here, though, there is more than one way to understand the normativity problem. It might seem as if the kind of knowledge that comes in with asking whether a given moral way of life is really how to live cannot be any kind of empirical knowledge, and so must either be knowledge of something nonempirical ("transcendent moral

Canadian Journal of Philosophy, Vol. 75, (2000): pg. 75-101. Publisher link. This article is (C) Taylor \& Francis and permission has been granted for this version to appear in e-Publications@Marquette. Taylor \& Francis does not grant permission for this article to be further copied/distributed or hosted elsewhere without the express permission from Taylor \& Francis. 
reality," "non-natural properties"), or nonempirical knowledge of something ("pure practical reason," "the logic of moral language"). But these moves to transcendence or to knowledge a priori throw in the towel on naturalized epistemology for morality. Alternately, we might hold that aside from what we know about how to get around in a "local moral world," there is no kind of moral knowledge left over to have. This idea, however, can be taken in more than one way. It can be taken to say that there is nothing that could be an answer to that "normative question."13 Or, on the contrary, it could be a starter for naturalizing moral epistemology. There is no knowledge "over and above," but there are further uses of the same kinds of naturally acquired moral knowledge we already have, together with whatever else about the world we think we know, to assess our and others' moral beliefs and our or others' ways of arriving at them.

\section{NATURALIZING MORAL KNOWLEDGE}

In line with this idea, now try a different naturalizing model, one that does not so much "extend" the naturalizing of science to ethics as take up the structural analogy for ethics.

(NME2) The epistemology of moral knowledge tells us under what conditions we have real knowledge of how we ought to live.

Moral epistemology must have a normative dimension, its inquiries must distinguish conditions under which we have genuine knowledge of how we ought to live from those under which we have something else (beliefs about how to live that are not warranted).

Moral knowledge is one kind of knowledge about the world (rather than about a transcendent or non-natural realm).

So, there is no kind of purely nonempirical knowledge that could validate moral knowledge.

Moral knowledge is knowledge about what understandings of how to live are "valid" (true/right/acceptable/deserving of authority.)

There is no kind of knowledge that can assess the moral validity of a way of life that does not include moral

Canadian Journal of Philosophy, Vol. 75, (2000): pg. 75-101. Publisher link. This article is (C) Taylor \& Francis and permission has been granted for this version to appear in e-Publications@Marquette. Taylor \& Francis does not grant permission for this article to be further copied/distributed or hosted elsewhere without the express permission from Taylor \& Francis. 
NOT THE PUBLISHED VERSION; this is the author's final, peer-reviewed manuscript. The published version may be accessed by following the link in the citation at the bottom of the page.

knowledge, no knowledge of the validity of values that does not include evaluative knowledge.

There is no kind of knowledge that without moral knowledge can be used to establish the validity of moral knowledge.

So, the account of how we have real knowledge of how we ought to live becomes another application of moral knowledge, i.e. we will use our best (presumptively genuine but always in principle fallible and revisable) moral and other knowledge of how to live to explain how we can come to such a thing as knowledge of how to live.

If we take seriously this approximation to a prototype for naturalizing moral knowledge, other facets of naturalized moral epistemology have to configure compatibly with it.

A naturalized moral epistemology will be holistic. But if we take (NME2) seriously, we need to rethink what kind of holism about knowledge it is plausible to endorse. "The" web of belief is a powerful image that retains the pleasing picture of knowledge as all of one piece, even as it jettisons the older architectural metaphor of a single structure with fixed foundations. But what is the status of the idea that knowledge is all of one piece? Surely an a priori conviction of the necessity of the unity of knowledge does not comport with a naturalized epistemology. Furthermore, (NME2) incorporates a commitment to natural moral knowledge. But if moral knowledge introduces a kind of normativity and forms of normative question open to natural investigation that some other types of natural knowledge cannot answer or explain, then it seems that moral knowledge (and perhaps other types of evaluative, practical, and craft knowledge) is a distinct type of knowledge, and we should not suppose that methods of discovery or patterns of validation are simply identical to or continuous with ones that obtain in other contexts. Finally, the image of "science" is apt to play a mystifying role in these discussions: is there a unified theoretical web of "science"? The "unity of science" represents a regulative ideal invested with philosophical hopes (akin, interestingly, to the reduction programs whose failure Quine remarks in introducing of the idea of naturalizing epistemology), not the known

Canadian Journal of Philosophy, Vol. 75, (2000): pg. 75-101. Publisher link. This article is (C) Taylor \& Francis and permission has been granted for this version to appear in e-Publications@Marquette. Taylor \& Francis does not grant permission for this article to be further copied/distributed or hosted elsewhere without the express permission from Taylor \& Francis. 
reality of a web of seamlessly interconnected theory, or even methods entirely homologous (much less uniform) in detail.

So it seems we have not enough reason to affirm a single web of belief, and some reasons not to. I suggest that a naturalized moral epistemology should opt for a contextual holism about knowledge. Instead of the view that every belief in the web is linked by some connections to all others, contextual holism would affirm only what we know: every belief is linked in some network of beliefs to indefinitely many others, including to normative standards that may be contextspecific. ${ }^{14}$ How and to what extent "webs" of belief overlap or intermesh is itself open to inquiry. Whether the "web" idea with its pleasing connotations of lithe transparency, springy flexibility, and tensile strength is apt for imaging the organization of our knowledges is to be explored. There is something after all very "unpragmatic," in its way, about Quine's web: it pictures a tissue of belief holistically hovering outside diverse action-repertoires, practices, relations, techniques and institutions that are involved in making available and vetting the status of beliefs. Open-ended contextual holism neither seals "morality" and "science" off from each other as separate language games nor preemptively unifies moral and scientific belief into a single field.

Of course, one approach to naturalism in ethics tries to preserve the autonomy of morality precisely by getting it out of the way of the secure path of science, lest it be "secured" (as in (NME1)) by the disappearance of ethics as a normative inquiry. ${ }^{15}$ This can be done by making morality something natural that is other than knowledge. In this category come noncognitivist and expressivist views. I sympathize with this move in that I think it a distortion to picture morality as only, essentially, or even primarily a matter of knowledge. This slights the complex economy of feelings and the expressive and directive aspects of our moral practice and discourse. But I consider ethics as pursuing an understanding of morality, which provides understandings of ourselves as bearers of responsibilities in the service of values.

\section{STOPPED HERE}

Instead, I reject two equations. One is the identification of Anatural@ or Aempirical@ knowledge exclusively with what can be known from within the world about the ways the world in fact is. The other is the equation of knowledge about how the world in fact is with scientific

Canadian Journal of Philosophy, Vol. 75, (2000): pg. 75-101. Publisher link. This article is (C) Taylor \& Francis and permission has been granted for this version to appear in e-Publications@Marquette. Taylor \& Francis does not grant permission for this article to be further copied/distributed or hosted elsewhere without the express permission from Taylor \& Francis. 
knowledge of the world. We sometimes know from within the world how the world might or could be for us, that is, how the world could be better or worse for us in some ways. Indeed, our knowing this is a condition for our understanding many ideas basic to morality, such as cruelty, suffering, and humiliation, or dignity, gratitude, and trust, and for identifying the states and relations these ideas represent. It is also true that much of our understanding of how the world in fact is and could be is available not only through common sense knowledge, but through refined and methodic inquiries that are not scientific, or are of the more dubiously scientific sorts. Humanistic and critical disciplines, like history, philosophy, critical social theory, historical and

critical studies of scientific practice, institutional genealogies, literature, literary studies, cultural studies, and semiotics, as well as in those scientifically lower-ranking social sciences and their still lower ranking parts, such as social psychology, sociological theory, ethnography, and their like, illuminate ways people live and how these ways are understood by those who live them. In sum, for moral knowledge and its improvement we must always use some of what we know about the world, and some of what we know that bears most crucially on moral knowledge and its refinement is not scientific knowledge. For a suitably generous naturalism, we and our experiences of the world and each other are in the world; how our world is, could be, and would be better or worse are among the things we can know from within our world about it.

In casting off global holism and scientifically regimented naturalism, I have pulled out the main struts of a Ascientism@ that can prop up some visions of naturalizing epistemology. Scientism is not (any) science, but an ideological vision of the cultural role and human significance of scientific knowledges. AScientism@ is a vision of a mythicized entity Ascience@ as the ultimate source of valid answers to anything worth knowing and the tribunal of what could possibly be taken seriously as a question. Scientism is really a full blown normative view; it is an ethics and a politics, not exclusively of knowledge, but inevitably of culture, authority, and society. That, however, is not something wrong with it. What=s wrong with it is its spurious regimentation of scientific practices into mythic Ascience, @ and it $=\mathrm{s}$ a priori imposition of incontestable and preemptive closure on our pursuits of understanding. What renders scientism ideological is its

Canadian Journal of Philosophy, Vol. 75, (2000): pg. 75-101. Publisher link. This article is (C) Taylor \& Francis and permission has been granted for this version to appear in e-Publications@Marquette. Taylor \& Francis does not grant permission for this article to be further copied/distributed or hosted elsewhere without the express permission from Taylor \& Francis. 
obscuring the variety, complexity, and fallibility of scientific practice, its claiming strictly universal (and necessary?) dominion in the realm of knowledge, and its borrowing the mantle of Ascientific objectivity@ when it is itself not science. Scientific inquiries

22

don=t need scientism. And naturalized epistemology should avoid the embarrassing irony of putting Ascience@ in the place of an incontestable and universal epistemic tribunal, which was exactly what classical epistemology is usually understood to have hoped itself to be. It will be necessary to repeat: I am not criticizing scientific inquiries or saying that scientific method is an ideology. It is scientism, not science, that has no place in a fallibilist and naturalized approach to epistemology.

Freed from confining and reductive pictures of knowledge, it becomes easier to acknowledge what is essential to a naturalist and naturalized knowledge of morality. Moral knowledge needs all the reliable and useful empirical information of any type that itBor rather weBcan get. Part of the point of seeing morality naturalistically is to dig into the idea that there is no prior restriction on what we could come to know about ourselves in our world that might not have implications for our beliefs about how to live. By the same token, moral knowledge is as open-ended, revisable, and ultimately fallible as any other kinds of natural knowledge. Here, as elsewhere, we use what we know, and accept that we are likely at any time to be wrong about something. And we must rest on some presumptive knowledge in order to examine where knowledge itself comes from, while this very examination may reveal that what we thought was knowledge was not what it appeared. A naturalized epistemology needs to be freewheeling and fallibilist, which is to say open to the best and most contextually useful fruits of all inquiries and experiences. And the naturalized epistemology of morality, in particular, seeks an understanding of moral knowledge that is necessarily both epistemically and morally reflexive.

\section{NORMATIVE QUESTIONS}

What now of that Anormative question, @ not a question of simply explaining the causes, 
NOT THE PUBLISHED VERSION; this is the author's final, peer-reviewed manuscript. The published version may be accessed by following the link in the citation at the bottom of the page.

\section{3}

organization, and effects of any individuals = or communities = moral behavior, but a question of establishing whether we must or should do what our going morality demands? This is a question about morality $=\mathrm{s}$ authority, not merely its de facto power but its rightful dominion over us. It is easy to start thinking that Athe normative question@ is one big jackpot question about Aall@ morality that arises from some reflective standpoint outside of or beyond morality. It can seem as if this is a sort of super-question that requires a sort of super-answer, that is, an answer to the question AIs it really right (obligatory, good, etc.)? @ that is of a different order from answers to those garden variety questions of Amust I really...? @ and Awould it really be wrong to...?@ or Ahow much does it really matter if I...?@that arise about different matters and at different levels of generality in people=s lives. I suspect that the idea that there is a separate, external question about morality=s authority is rooted deeply in non-naturalist, and perhaps supernaturalist, thinking about morality that yearns for its validation by something Ahigher, @ be that God, human nature, the natural law, pure practical reason, or perhaps Ascience.@ Even theories of ethics that understand it as a human construction, like a procedure, or a contract, or a discursive situation, still often think that the construction that could answer the normative question must be an ideal construction. This is the idea that nothing any group of people is doing at a place at a time isBindeed, could possibly beBour touchstone in ethics when we ask whether a way to live really has authority.

But there cannot be just one normative question. For one has to stand on some part of morality to pose a normative query about some other; and there is always at least the possibility (although it is not inevitable) that the moral judgment on which one stood for those purposes at that time might come in question at some other. AThe@ normative question is not one question,

\section{4}

but a kind of question that recurs applied to different matters or reapplied to earlier answers. And there is no way for it to be posed Aoutside@ some moral assumptions or other.

The situation is no different for moral theorists. As naturalists, we do not hesitate to look at the facts about the formation of moral beliefs.

Canadian Journal of Philosophy, Vol. 75, (2000): pg. 75-101. Publisher link. This article is (C) Taylor \& Francis and permission has been granted for this version to appear in e-Publications@Marquette. Taylor \& Francis does not grant permission for this article to be further copied/distributed or hosted elsewhere without the express permission from Taylor \& Francis. 
The fact is that what and how we can think about morality depends on what we have learned in the context of our places within particular ways of life, questions within them, and perhaps comparisons between them and others ways more or less comparable. In fact, then, Areflection, @ in moral philosophy or outside it, is on or of, or better from, some bits of (putative) moral knowledge, some already familiar forms of moral reasoning, some extant norms of responsibility, that allow us to know that it is morality, what is right and good, that we are thinking about here. Moreover, a large mass of critical work in late twentieth century maps the deliverances of Areflection@ in moral philosophy onto specific locations in a given social field: moral theorizing Areflects@ characteristic roles, expectations, and lifeexperiences or the absence of experiences that track race, education, national culture, religious heritage and practice, economic status, gender, age, sexuality, physical ability and other factors that account for different social worlds or very different experiences within the same social world.16

16 See Walker, Moral Understandings, especially Chapter 1-3 for a critique of epistemic placelessness and lack of reflexivity in moral theorizing, as well as structural and historical analysis of the emergence of the Atheoretical-juridical model@ of compact theory, See also Chapters 1 and 3 for examination of the feminist critique of gender and other bias in moral theorizing.

\section{5}

Better to recognize going in that actual moral ideas, practices, norms, patterns of reasoning, and paradigmatic judgments are in fact always in play in moral philosophy at the outset. The philosopher no more asks after the moral authority of Amorality@ from outside of it than does anyone reflecting on moral demands when the garden variety questions work their way to the surface out of confusion, temptation, longing, or ennui. The moral philosopher may be more relentless, more systematic, and more logically acute in pursuing normative questions. She may invent in thought startlingly simple or idealized or schematic moral views the social realization of which may or may not be determinate, available, or habitable in reality; this, too, may have its uses. But in all cases of moral reflection, she starts where we all do: we start from here, for some Awe,@ and some Ahere.@

Canadian Journal of Philosophy, Vol. 75, (2000): pg. 75-101. Publisher link. This article is (C) Taylor \& Francis and permission has been granted for this version to appear in e-Publications@Marquette. Taylor \& Francis does not grant permission for this article to be further copied/distributed or hosted elsewhere without the express permission from Taylor \& Francis. 
In moral theorizing, as at other times, we resort in all cases to what Christine Korsgaard calls Areflective endorsement.@17 If we are able to endorse morality once we understand what about us and world, especially our actual social world, grounds and enables the morality we have, or if we can endorse a change based on the comparison between what we have and what we might, based on these same understandings, then this justifies the extant or revised morality $=s$

17 Korsgaard=s initially naturalistic treatment of Areflective endorsement@ as the way to answer the normative question unfolds into a argument for the universality and necessity of our valuing our humanity as a condition for acting on reasons, hence bringing back in a bit of the old apriori when it comes to securing morality. This view makes for interesting comparison with the naturalized version of reflective endorsement of actual ways of living. See Korsgaard, The Sources of Normativity, Lectures 2 and 3.

\section{6}

authority, its Anormativity.@ Reflection can thus produce or sustain, as it can defeat or chasten, confidence in the claims morality makes on us. But we can only test our moral views by finding them good or not upon reflective examination. So the normative question requires the application of some morally normative standards or judgments in the vetting of others.

What results when some of our moral practices, judgments, or concepts pass moral review, is that our confidence in aspects of ways we live is confirmed or perhaps enlivened; when they fail it is weakened or destroyed. But it is not as if there are our moral beliefs and our (always in part moral) reasons for them, and then there is our Aconfidence@ in them, the way a cherry sits on a sundae. AConfidence@ is not something we might have or not have about those standards we hold as moral ones. When we hold some ways we in fact live as Ahow to live,@ i.e. the right or better founded or more enlightened ways, this way of holding certain standards marks them as morally authoritative ones. When confidence wanes or is damaged, we are inclined to wonder whether the standards we have held as moral ones are in fact standards of some other kind (for example, etiquette or mores) or whether we have held the wrong moral standards. So, too, confidence does not replace knowing what is right or good; it is

Canadian Journal of Philosophy, Vol. 75, (2000): pg. 75-101. Publisher link. This article is (C) Taylor \& Francis and permission has been granted for this version to appear in e-Publications@Marquette. Taylor \& Francis does not grant permission for this article to be further copied/distributed or hosted elsewhere without the express permission from Taylor \& Francis. 
confidence in our knowing at least some of, or approximately, what is right or good. Our standards and judgments (or some specially central or important ones of them) being, literally for all we know, valid constitutes the moral authority of morality, whatever other powers of de facto social authority and inertial social practice hold the standards and supporting practices in place. 18

18 Compare Bernard Williams=s somewhat elusive appeals to Aconfidence@ in Bernard Williams, Ethics and The Limits of Philosophy, (Cambridge, Mass.: Harvard University Press,

\section{7}

1985), 170-3. See also J. E. J. Altham, AReflection and confidence,@ in World, mind, and ethics: essays on the ethical philosophy of Bernard Williams, ed. J. E. J. Altham and Ross Harrison (New York: Cambridge University Press, 1995) and Williams, AReplies@ in the same volume. While Williams seems to consider confidence an alternative to knowledge, I see our confidence as a kind of trust in what we know.

\section{8}

Naturalized epistemology of science needs to investigate beliefproducing cognitive, social, and institutional processes with an eye to uncovering whether or not they are conducive to the kinds of truth the sciences seek, and in doing so uses with confidence what it seems most reasonable to think we already know.19 Moral epistemology, whether practiced systematically by philosophers or in the event by any thoughtful agent, needs to investigate belief-producing cognitive, social, and institutional processes with an eye to uncovering whether or not they are conducive to the kinds of worth upon which a moral form of life rests its authority or in terms of which its authority is understood. But Aworth@ here is a dummy expression for some form of value or necessity that will not be identifiable independently of some standards of moral judgment already in hand. Indeed, we can not so much as characterize what our or someone else $=\mathrm{s}$ form of moral life is without importing some understandings of what to identify as the moral parts, and in what sort of evaluative language to identify them. Wherever we invoke some moral concepts, standards, and judgments to test whether some others Areally@ have the authority they purport, the ones we invoke are invested with our confidence in their

Canadian Journal of Philosophy, Vol. 75, (2000): pg. 75-101. Publisher link. This article is (C) Taylor \& Francis and permission has been granted for this version to appear in e-Publications@Marquette. Taylor \& Francis does not grant permission for this article to be further copied/distributed or hosted elsewhere without the express permission from Taylor \& Francis. 
representing what we (already) reasonably understand to matter morally. This does not prevent the very commitments in which we have reposed confidence from becoming objects of critical reflection in their turn.

An open-minded and empirically robust naturalism about morality readily discovers that morality is not socially modular: moral understandings are (indeed must be) effected through social arrangements, while social arrangement include moral practices as working parts. Our concepts and principles are given meaning by the practices they in turn make sense of. For this

19 See Kornblith, AA Conservative Appproach to Social Epistemology,@102ff.

\section{9}

reason there is not nor could there have been a Apure core@ of moral knowledge completely extricable from some actual social world or other.20 That is why moral knowledge requires extensive empirical inquiry and intensive reflexivity about both the moral and non-moral conditions under which we believe we know how to live.

A central mode of examination of our moral understandings is Atransparency testing, @ which involves both moral and epistemic aspects.21 We need to ask whether we in fact know how it is we do live in our moral-social worlds. In fact, in most societies, Awe@ do not all live the same lives, and Awe@ often fail to understand or do not try to understand how the places our moral-social worlds provide for us are the conditions for the very different places of others of us. Our intermeshed moral and social understandings may be incomplete, selfserving, distorting, or rigged; they may render the lives of some of us morally invisible, incoherent, or diminished. The moral values we Ashare@ may be ones we do not equally freely endorse or enjoy. We need to

20 See Walker, Moral Understandings, Chapters 2, 3, and 9 on the genealogy and implications of the Apure core@ idea.

21 The idea of Atransparency@ as an ideal of moral views or social orders appear in Williams, Ethics and the Limits of Philosophy, 101-10, and Korsgaard, Sources of Normativity, 17. Although she does not use the phrase, I have profited most from Annette Baier=s application of

Canadian Journal of Philosophy, Vol. 75, (2000): pg. 75-101. Publisher link. This article is (C) Taylor \& Francis and permission has been granted for this version to appear in e-Publications@Marquette. Taylor \& Francis does not grant permission for this article to be further copied/distributed or hosted elsewhere without the express permission from Taylor \& Francis. 
what she calls a Aminimal condition of adequacy@ that a moral view Anot have to condemn the conditions needed for its own thriving,@ that it not fail to acknowledge or deny acknowledgment to that which is a condition of its working as it does. See Baier, Moral Prejudices, 96.

30

discover whether what are represented as morally authoritative understandings are ones whose authority is or is not really earned by their being shown answerable to well-founded fact and critically tested moral standards. We need to explore whether practices that purport to embody values, standards, and judgments Awe@ share and in which Awe@ trust are really driven and reproduced by coercion, deception, manipulation, or violence directed at some of us by others. Where transparency testing of our actual lifeways does not sustain confidence that Awe@ know either how we do live or how to live, the understandings in play lose their moral authority. Then we really are left with mere customs, habits, or mores; with ways some people in fact live that are no longer credible as Ahow to live.@ But to discover whether authority is warranted and confidence is in point, we must bring to bear a lot of, and the most relevant and reliable, information we have about morality and society. This is especially so in moral theorizing and moral epistemology, where we are promised a high degree of sophisticated scrutiny of the tenability of moral conceptions. 22

\section{WHAT DO AWE@ KNOW BEST?}

I have argued against a purely scientific naturalism, or a scientifically insupportable Ascientism, @ lest we claim prematurely or irresponsibly for scientific theories or findings a relevance to morality that they do not have, or that we do not know they have. A different danger

22 The thorough intermeshing of moral and epistemic considerations in the reciprocal relationship between understanding who we are, how we live, and how to live, might be a very rich case of what Richmond Campbell calls Afact-value holism.@ See Campbell, Illusions of Paradox, Chapter 7.

\section{1}

for naturalists, and perhaps a greater, is that preoccupation with science as our best empirical knowledge can turn our attention away

Canadian Journal of Philosophy, Vol. 75, (2000): pg. 75-101. Publisher link. This article is (C) Taylor \& Francis and permission has been granted for this version to appear in e-Publications@Marquette. Taylor \& Francis does not grant permission for this article to be further copied/distributed or hosted elsewhere without the express permission from Taylor \& Francis. 
from other kinds of inquiry that bear deeply and directly on our understandings of how we live and how to live. Between the Scylla of scientific naturalism about morality, and the Charybdis of a transcendent moral reality accessible to Apure@ reflection, lies a great deal we can and already do know about our social worlds and moral theories and traditions that is crucial for testing our moral understandings. Above I mentioned humanistic disciplines, critical studies, and the methodologically less rigorous parts of social and political theory and sciences as important resources for moral reflection, that is, for reflection on actual forms of life that claim moral authority for those who live them (and perhaps beyond). Some contemporary philosophical theorizing itself, empirically attentive and reflexively critical about its empirical burdens and moral commitments, offers moral reflection and moral theory materials it cannot honestly proceed without.

I am going to use here, very briefly, a single example of such empirically enriched but normatively motivated work that sharply focuses a point about the kinds of things moral philosophy needs to examine and who is likely to want to find them out. Charles W. Mills=s The Racial Contract constructs a deliberately stylized theoretical model to foreground both Athe most important political system of recent global historyBthe system of domination by which white people have historically ruled over and, in certain important ways, continue to rule over nonwhite people; @ the invisibility of this system and the issues it raises in mainstream ethics and political philosophy; the obscurity to, or outright denial of, this system by most white people;

\section{2}

and the intimate relations among these. 23 Specifically, Mills argues that the tradition of social contract theory, still a hugely influential tributary of modern Euro-American moral and political theory, cannot be understood in its normative implications and historical reference without seeing the broad and deep Racial ContractBa set of interlocking political, moral, and epistemological assumptions and their effectsBthat underwrites it.24 Mills, in effect, proposes that if contractarian models are honored devices in philosophy for exposing the logic of liberal political legitimacy, we ought to consider their potential for diagnosing the logic of politically legitimated racism in liberal polities. More broadly, Mills asks us to try examining the 
apparent contradiction of modern European moral philosophy as such: A....an antipatriarchalist Enlightenment liberalism, with its proclamations of equal rights, autonomy, and freedom of all

23 Charles W. Mills, The Racial Contract (Ithaca: Cornell University Press, 1997), 1; hereafter cited as RC in the text.

24 Among the facets of the Racial Contract Mills connects with the massive and grim historical record are: a Apartitioned social ontology@ and juridical elaboration of persons and racial subpersons (14); a racial polity that is obligated to the privilege of necessarily white citizens at the expense of nonwhites (12); a racialized geography that placed most human beings in a irremediable state of nature (13), their lives uncounted (49-50) and their lands unpeopled (49); an Aepistemology of ignorance@ that precludes understanding of social and political realities (18), produces Amoral cognitive distortions@(95) and disqualifies cognition or cultural production of non-Europeans (44).

\section{3}

men, thus took place simultaneously with the massacre, expropriation, and subjection to hereditary slavery of men at least apparently human@ (RC, 64).

In what he describes as a Anaturalized@ ethical account, Mills makes use of the large and expanding body of historical, demographic, anthropological, and critical studies of race, colonialism, modern European history, economic development, and exploitation of nonEuropean lands and peoples. He also pays critical attention to aspects of philosophy=s own history and to specific texts that have been passed over silently or left out of sight in perpetuating a particular version of a canonical history of philosophy. Mills $=s$ project is not a grand unified explanatory theory but a morally and epistemically strategic intervention, a Arhetorical trope and theoretical method@ $(R C, 6)$ for reorganizing perceptions of fact and by doing so posing questions about what theories and professional discourses of moral and political philosophy have seemed interested or uninterested in knowing about our world. If one looks where he does determinedly enough, it becomes a good deal harder to think, or not to think about, some things. It becomes harder to think that Kant and other modern European thinkers created visions of an ideal moral polity and merely

Canadian Journal of Philosophy, Vol. 75, (2000): pg. 75-101. Publisher link. This article is (C) Taylor \& Francis and permission has been granted for this version to appear in e-Publications@Marquette. Taylor \& Francis does not grant permission for this article to be further copied/distributed or hosted elsewhere without the express permission from Taylor \& Francis. 
failed, due to lamentable but local prejudice, to imagine certain people within it. Mills makes a compelling case by direct textual and inductive historical evidence that it was integral to the construction of that ideal polity that certain people be imagined outside it. One is dignified not only by what one is, but by what, or rather whom, one is not. 25

25 For a primer of short and disturbing selections that exhibit the modern construction of race within Enlightenment terms by Enlightenment thinkers, see Emmanuel Chukwudi Eze, ed., Race and the Enlightenment: A Reader (Cambridge, Mass: Blackwell Publishers, 1997). Two

\section{4}

sobering historical studies that document the enormous energy and evasion needed by Europeans to avoid the simplest path of taking Africans or indigenous people as simply other human beings who lived differently, even exotically differently, from Europeans are Olive Dickason=s study of early North American colonization in the Northeast, The Myth of the Savage: And the Beginnings of French Colonialism in the Americas (Edmonton: The University of Alberta Press, 1984, 1987), and Winthrop D. Jordan=s White Over Black: American Attitudes Toward the Negro, 1550-1812 (Chapel Hill: The University of North Carolina Press, 1968).

\section{5}

An ostensibly Auniversalist@ tradition of ethical thinking about Aman,@ Ahuman nature,@ and Ahumanity@ in Western philosophy, from ancient to contemporary times, has in fact consistently been understood and intended not to apply to the majority of humankind, female and nonwhite. Yet is seems to depend on who moral theorists are, and on to whom they give their accounts and are accountable, whether they will question the significance of this. The ostensible universalism of most contemporary moral philosophy and the bowdlerized universalist presentation of its history conceals the actual history in which the enunciation of Auniversal@ truths has not only coexisted with but has served persisting social practices of dividing, excluding, stratifying, subordinating, degrading, and dehumanizing the larger part of humankind. Most moral philosophers continue to import assumptions about the uniformity of moral intuitions, standard conditions of responsibility, or the universal recognizability of 
Acommon humanity, @ in a way that disguises the ways moral perceptions are characteristically formed in societies in which social and moral differentiation is nearly universally the rule.26 Do we know

26 The importance for moral philosophy of recognizing, not ignoring or obscuring, the pervasive fact of differentiated social-moral positions in human societies is a main theme of Moral Understandings. I have elsewhere examined several philosophers $=$ arguments that presuppose, while purporting to prove, that recognizing the Acommon humanity@ of other human beings is in some sense unavoidable. Sadly, it has been and continues to be avoided in numerous forms more often than not by human beings. See Margaret Urban Walker, AIneluctable Feelings and Moral Recognition,@ in Midwest Studies in Philosophy, Volume XXII: The Philosophy of Emotions, ed. Peter A. French and Howard K. Wettstein (Notre Dame, Ind.: University of Notre

\section{6}

whether our systems of moral philosophy even now are free of conceptual features or substantive assumptions that continue the actual tradition and the understandings it has in fact required? Do we routinely and methodically make sure that we use what we know to find out? Do Awe@ really know more about the evolution of social cooperation than about recent histories and ongoing dynamics of social subordination or imperialism? Or do these questions not seem important enough, or philosophical enough, for Aus@ to address? It depends on who we are.

In fact, it is overwhelmingly women who have explored the sexism of ethical theory; people of color, ethnically marginalized people, or indigenous people who have insisted that we know about racism or colonialism; gay, lesbian, and transsexual theorists who ask us review the moral intuitions of a hetero-normative cultural universe critically. Not all of Aus@ know what others do, and not all of us try to, or care to.

Louise Antony says naturalizing knowledge Arequires us to give up the idea that our own epistemic practice is transparent to us...@27 So too for our moral practice, and the epistemic practice, moral philosophy, that seeks to know it, from within it. In moral epistemology, we cannot but ask ourselves what we know best about science, morality, and

Canadian Journal of Philosophy, Vol. 75, (2000): pg. 75-101. Publisher link. This article is (c) Taylor \& Francis and permission has been granted for this version to appear in e-Publications@Marquette. Taylor \& Francis does not grant permission for this article to be further copied/distributed or hosted elsewhere without the express permission from Taylor \& Francis. 
NOT THE PUBLISHED VERSION; this is the author's final, peer-reviewed manuscript. The published version may be accessed by following the link in the citation at the bottom of the page.

social life, and how we know it. Yet here it is epistemically and morally urgent that we open the question that Moore

Dame Press, 1998).

27 Louise M. Antony, AQuine as Feminist, @ in A Mind of One=s Own: Feminist Essays on Reason and Objectivity, ed. Louise M. Antony and Charlotte Witt (Boulder, Colo.: Westview Press, 1993), 202.

\section{7}

would never have asked: who are Awe@? And how, in point of fact, do we know that?28

28 I thank John Greco, Richmond Campbell, and Bruce Hunter for their helpful comments on an earlier draft. An opportunity to present a shorter version of this paper in a symposium on naturalized moral epistemology at the Canadian Philosophical Association in Edmonton, May, 2000, helped me to rethink the final form of this essay. I thank the CPA for this invitation.

\section{Endnotes}

1. My view is developed in Margaret Urban Walker, Moral Understandings: $A$ Feminist Study in Ethics (New York: Routledge, 1998).

2. W. V. Quine, "Epistemology Naturalized," in Ontological Relativity and Other Essays (New York: Columbia University Press, 1969), hereafter cited as EN in the text.

3. Richmond Campbell claims that Quine views science as "free of" the effect of value judgments, but acknowledges that Quine in at least one context speaks of empiricism as a theory of evidence that "has both a descriptive and a normative aspect" ("On the Very Idea of a Third Dogma" in Theories and Things (Cambridge, Mass.: Harvard University Press, 1981), 39, and 41 on the "empiricist discipline" that makes for "more or less responsible science"). See Richmond Campbell, Illusions of Paradox (Lanham, Maryland: Rowman \& Littlefield Publishers, 1998), Chapter 5. A useful discussion that rejects the "no normativity" view, but recognizes ambiguity in Quine's position about normativity is Richard Foley, "Quine and Naturalized Epistemology," in Midwest Studies in Philosophy, Volume XIX: Philosophical Naturalism, ed. Peter A. French, Theordore E. Uehling, Jr., and Howard K. Wettstein (Notre Dame, Ind.: University of Notre Dame Press, 1994). Certainly for Quine it is no business of science to judge how the world ought to be, but this is not the same as judging what science ought to do in constructing and revising its

Canadian Journal of Philosophy, Vol. 75, (2000): pg. 75-101. Publisher link. This article is (C) Taylor \& Francis and permission has been granted for this version to appear in e-Publications@Marquette. Taylor \& Francis does not grant permission for this article to be further copied/distributed or hosted elsewhere without the express permission from Taylor \& Francis. 
picture of the world. And Quine invokes predictive success, conservatism in accommodating recalcitrant experiences, and simplicity of laws, as considerations in revising our web of belief (see, for example, W. V. Quine, "Two Dogmas of Empiricism," The Philosophical Review 60 (1951), 20-43). Quine seems to like to label these appeals "tendencies" and "inclinations," but this doesn't disguise the fact that they are normative, i.e. parts of the practice of doing good science. See, finally, Quine's later discussion in Pursuit of Truth (Cambridge, Mass.: Harvard University Press, Revised Edition, 1992), Chapter 1, 19-21, which calls naturalized epistemology a "chapter of engineering: the technology of anticipating sensory stimulation" (19) concerned with heuristics, with "the whole strategy of rational conjecture in the framing of scientific hypotheses" (20). Here Quine considers the constraint of predictive power not normative but constitutive of a "languagegame" of science. These later views are in some respects more congenial to my own picture of naturalizing moral epistemology; but I believe it is Quine's earlier views that have set the tone for dominant conceptions of what "naturalizing" is.

4. W. V. Quine, "Natural Kinds," in Ontological Relativity and Other Essays (New York: Columbia University Press, 1969), 138. See also "Five Milestones of Empiricism," in Theories and Things (Cambridge, Mass.: Harvard University Press, 1981), 72. Peter Hylton makes a good case that Quine's naturalism can go so far as to reject empiricism if science, improbably, validated nonsensory forms of knowledge like telepathy and clairvoyance (the examples are Quine's own). See Peter Hylton, "Quine's Naturalism," in Midwest Studies in Philosophy, Volume XIX: Philosophical Naturalism, ed. Peter A. French, Theordore E. Uehling, Jr., and Howard K. Wettstein (Notre Dame, Ind.: University of Notre Dame Press, 1994).

5. Lorraine Code presents a detailed diagnosis and critique of the tendentious and unsupported assumptions about science, scientific psychology, and nature that structure Quinean naturalized epistemology. Although she does not discuss naturalized moral epistemology, her critique powerfully exposes the non-scientific ethos of scientism at several levels. See "What is Natural About Epistemology Naturalized?" American Philosophical Quarterly 33 (1996): 1-22. See also, Tom Sorrell, Scientism: Philosophy and the Infatuation with Science (London: Routledge, 1991), cited by Code.

6. Quine's own meager views on ethics confirm that science will be judge of ethics, at least: ethics is "methodologically infirm," because "lacking in empirical checkpoints" for those ends that cannot be shown instrumental (Quine says "causally reduced") to others. Our moral judgments, as also our propensity to extrapolate from some applications of ethical standards to others, can only answer back to our "unsettled" moral standards themselves, so "coherence" only and "no comparable claim to objectivity" is the lot of

Canadian Journal of Philosophy, Vol. 75, (2000): pg. 75-101. Publisher link. This article is (C) Taylor \& Francis and permission has been granted for this version to appear in e-Publications@Marquette. Taylor \& Francis does not grant permission for this article to be further copied/distributed or hosted elsewhere without the express permission from Taylor \& Francis. 
NOT THE PUBLISHED VERSION; this is the author's final, peer-reviewed manuscript. The published version may be accessed by following the link in the citation at the bottom of the page.

ethics. See "On the Nature of Moral Values," in Theories and Things (Cambridge, Mass.: Harvard University Press, 1981), 63-65. Below I return to the idea that moral standards answer back to moral standards, although also to the experience of the world of those who live in social worlds in which these standards have authority.

7. Hilary Kornblith, "A Conservative Approach to Social Epistemology," in Socializing Epistemology: The Social Dimensions of Knowledge, ed. Frederick F. Schmitt (Lanham, Maryland: Rowman \& Littlefield, 1994), 96.

8. I'm using "warranted belief" here in the fairly open sense that Michael DePaul does as "meeting standards that identify what would be epistemically good, excellent, or best." See Michael DePaul, Balance and Refinement (New York: Routledge, 1993), 74.

9. I like to think that this model could be adapted to characterize the justification of certain moral sensibilities, attitudes, or endorsings of norms if moral judgments are explained as expressive rather than descriptive, but I do not attempt to show this here. See Alan Gibbard, Wise Choices, Apt Feelings: A Theory of Normative Judgment (Cambridge, Mass.: Harvard University Press, 1990) and Simon Blackburn, Ruling Passions: A Theory of Practical Reasoning (Oxford: Oxford University Press, 1998) for expressivist views.

10. I neither affirm nor deny " $a$ " or "the" fact/value distinction, being uncertain what it means but certain that it means different things to different people. I consider ethical propositions bona fide propositions; but ethical propositions have distinctive and, I believe, multiple roles to play within practices of responsibility structuring social life. These roles include descriptive, expressive, directive, and perhaps other aspects.

11. The empirical-scientific study of morality is a not, of course, a "value-free" enterprise. Few today will deny that scientific knowledge is imbued with epistemic norms, if not other kinds. Feminist epistemology has produced the most sustained contemporary philosophical defense (in varied forms) of the claim that scientific knowledge is also inescapably constrained or driven either by non-epistemic (for example, social, moral, and political) norms. For two good samplers, see Linda Alcoff and Elizabeth Potter, eds., Feminist Epistemologies (New York: Routledge, 1993) and Louise Antony and Charlotte Witt, eds., A Mind of One's Own: Feminist Essays on Reason and Objectivity (Boulder, Colo.: Westview Press, 1993). Some classics are: Lorraine Code, What Can She Know? (Ithaca: Cornell University Press, 1991); Sandra Harding, The Science Question in Feminism (Ithaca: Cornell University Press, 1986); Helen E. Longino, Science as Social Knowledge (Princeton: Princeton University Press, 1990); Lynn Hankinson Nelson, Who Knows? (Philadelphia: Temple University Press, 1990); Donna Haraway, Simian, Cyborgs, and Women (New York: Routledge, 1991) Naomi Scheman, Engenderings (New

Canadian Journal of Philosophy, Vol. 75, (2000): pg. 75-101. Publisher link. This article is C) Taylor \& Francis and permission has been granted for this version to appear in e-Publications@Marquette. Taylor \& Francis does not grant permission for this article to be further copied/distributed or hosted elsewhere without the express permission from Taylor \& Francis. 
NOT THE PUBLISHED VERSION; this is the author's final, peer-reviewed manuscript. The published version may be accessed by following the link in the citation at the bottom of the page.

York: Routledge, 1993). See also Richmond Campbell, Illusions of Paradox (Lanham, Maryland: Rowman and Littlefield Publishers, 1998) for a recent defense of feminist empiricism.

12. One collection that takes up a variety of issues surrounding the meanings of naturalism and the relevance of empirical studies to moral philosophy is Larry May, Marilyn Friedman, and Andy Clark, eds., Mind and Morals: Essays on Ethics and Cognitive Science (Cambridge, Mass.: MIT Press, 1996).

13. The phrase "the normative question" is the centerpiece of Christine Korsgaard's The Sources of Normativity (Cambridge: Cambridge University Press, 1996).

14. Wittgenstein's fitful but insightful treatment of the grammar of knowledge is one standard locus for this view in On Certainty, ed. G. E. M. Anscombe and G. H. von Wright, trans. Denis Paul and G. E. M. Anscombe, (New York: Harper \& Row, 1972). See also Michael Williams, Unnatural Doubts: Epistemological Realism and the Basis of Skepticism (Cambridge, Mass.: Basil Blackwell, 1991), which rejects a global view of knowledge.

15. See Stephen Darwall, Allan Gibbard, Peter Railton, AToward Fin de siècle Ethics: Some Trends, @ Philosophical Review 101 (1992): 115-89 for an anatomy of some contemporary metaethics organized by the issue of "placing" ethics with respect to "empirical science as the paradigm of synthetic knowledge." (The authors attribute the terminology of placing to Simon Blackburn.) In a footnote, they demur from the view that "objective knowledge" has a definite meaning and deny that it amounts to "knowledge as attained in the empirical sciences," leaving room for alternative conceptions of objectivity, as well as the corrective impact of an alternative conception of ethical objectivity upon understanding of objectivity in mathematics and science (see page 126, note 29). But the authors= admonitory remark that "Such 'placement' would enable us to see how much of morality remains in order" shows their own investment in the tribunal of science. In contrast, see John McDowell's "Two Sorts of Naturalism," which chastises "neo-Humean naturalism" in favor of a reality that encompasses our "second," moral natures, in Virtues and Reasons: Philippa Foot and Moral Theory, ed. Rosalind Hursthouse, Gavin Lawrence, and Warren Quinn (Oxford: Oxford University Press, 1995). But see also essays on Humean epistemology and naturalism in Annette Baier's Moral Prejudices: Essays on Ethics (Cambridge, Mass.: Harvard University Press, 1995). There are varied alternatives to scientific naturalism, not all mutually compatible.

Canadian Journal of Philosophy, Vol. 75, (2000): pg. 75-101. Publisher link. This article is (c) Taylor \& Francis and permission has been granted for this version to appear in e-Publications@Marquette. Taylor \& Francis does not grant permission for this article to be further copied/distributed or hosted elsewhere without the express permission from Taylor \& Francis. 
NOT THE PUBLISHED VERSION; this is the author's final, peer-reviewed manuscript. The published version may be accessed by following the link in the citation at the bottom of the page.

Canadian Journal of Philosophy, Vol. 75, (2000): pg. 75-101. Publisher link. This article is (c) Taylor \& Francis and permission has been granted for this version to appear in e-Publications@Marquette. Taylor \& Francis does not grant permission for this article to be further copied/distributed or hosted elsewhere without the express permission from Taylor \& Francis. 
NOT THE PUBLISHED VERSION; this is the author's final, peer-reviewed manuscript. The published version may be accessed by following the link in the citation at the bottom of the page.

Canadian Journal of Philosophy, Vol. 75, (2000): pg. 75-101. Publisher link. This article is (c) Taylor \& Francis and permission has been granted for this version to appear in e-Publications@Marquette. Taylor \& Francis does not grant permission for this article to be further copied/distributed or hosted elsewhere without the express permission from Taylor \& Francis. 